\title{
VITAL STATISTICS OF THE COUNTY OF LONDON IN THE YEARS 1901 TO 1951
}

BY

\author{
W. J. MARTIN
}

Medical Research Council's Statistical Research Unit, London School of Hygiene and Tropical Medicine

The growth and development of London during the past 50 years has been influenced by three major factors. The first factor to operate, and one which still functions, is the continuous growth of London as a commercial centre and the consequent pressure exerted on living conditions by the creation of new offices, shops, warehouses, and factories, especially in the central areas. Secondly, the first world war brought about a social revolution, and perhaps one of its most important consequences was the large increase in opportunities for female labour in office and factory. Thirdly, during the second world war, thousands of houses in London were destroyed, and a very severe housing shortage ensued. With the publication of the 1951 Census for London it is possible to see how these factors have influenced the vital statistical trends of the different London boroughs during the last half century.

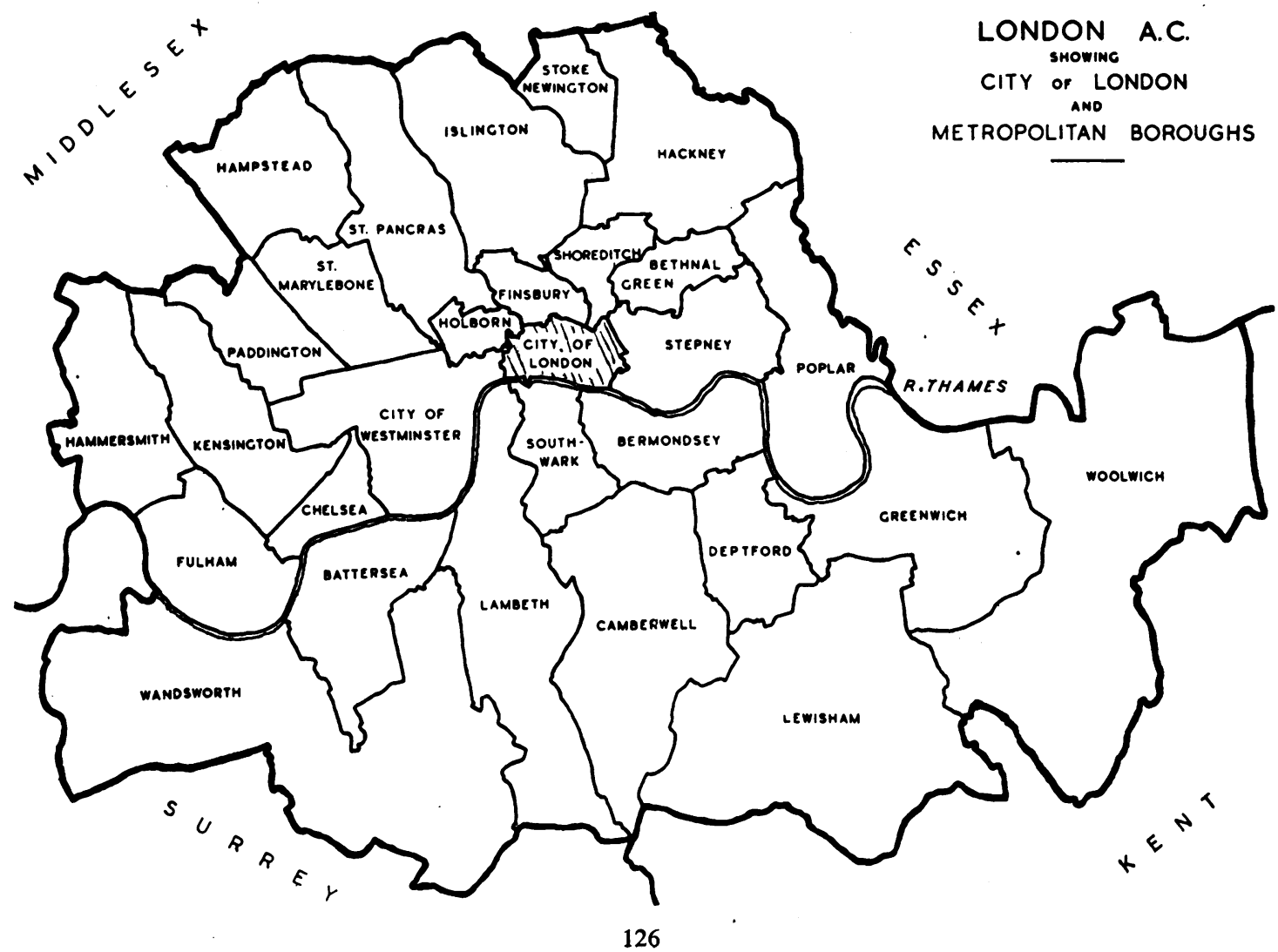




\section{Population}

At the beginning of the 20th century London had already overflowed its boundaries in the east and the north-east where other towns had become contiguous with London. Some boroughs were not completely built up and in the north-west and south some land was still used for agriculture and wild life still persisted. Since horse vehicles and steam trains were the only methods of transport, most members of the population were compelled to live fairly close to their places of employment. The development of electricity for traction in the first decade of the 20th century led to the electrification of some suburban train services, the district and metropolitan railways, and the construction of the underground system of "tubes". Further electrification and the introduction of the motor bus greatly facilitated travelling; the centre of London became more commercialized and surrounding country was engulfed for dormitories.

Table I shows the population enumerated at the last five censuses and the changes that have occurred in the distribution of the population during the past 50 years. The central cluster of boroughs (including the City, Finsbury, Holborn, St. Marylebone, Southwark, and Westminster) showed a continuous decline in population during the first 30 years and much house property was converted to commercial uses. On the other hand the outer boroughs, and those incompletely built-up boroughs in 1901 (Fulham, Hammersmith, Hampstead, Lewisham, Wandsworth, and Woolwich) showed consistent rises. The changes in the distribution of population between 1931 and 1951, particularly the large falls in population in the adjacent boroughs of Bermondsey, Bethnal Green, Finsbury, Poplar, Shoreditch, Southwark, and Stepney, reflect the damage done during the war. In all these districts the 1951 population was approximately only half the 1931 level. Only in Hampstead, Lewisham, and Woolwich did the population of 1951 exceed that of 1931 , and the gains here were very slight.

The best residential districts in 1901 were situated in Hampstead and Kensington, and the large number of female domestic staff employed accounts for the very low proportion (39 per cent.) of males in the population of these boroughs. Despite the disappearance of large domestic staffs, the great preponderance of women in these areas persisted until 1951. The occupational section of the 1951 Census is not yet published, but it is probable that the excess female population is due to women in personal service in the hotels and boarding houses to which the large private houses were converted in many instances. Similarly the excess of females in some other boroughs-Chelsea, Holborn, Paddington, and St. Marylebone-is probably due to the many hotels which are here situated. The City, Bermondsey,

TABLE I

POPULATIONS OF BOROUGHS

\begin{tabular}{|c|c|c|c|c|c|c|c|c|c|c|c|c|c|c|c|}
\hline \multirow{2}{*}{ Borough } & \multirow[b]{2}{*}{. } & \multicolumn{5}{|c|}{ Populations (thousands) } & \multicolumn{4}{|c|}{ Intercensus Variations (per cent.) } & \multicolumn{5}{|c|}{ Percentage of Males in Population } \\
\hline & & 1901 & 1911 & 1921 & 1931 & 1951 & $1901-11$ & $1911-21$ & $1921-31$ & $1931-51$ & 1901 & 1911 & 1921 & 1931 & 1951 \\
\hline $\begin{array}{l}\text { City ... } \\
\text { Battersea ... } \\
\text { Bermondsey } \\
\text { Bethnal Green } \\
\text { Camberwell } \\
\text { Chelsea .. } \\
\text { Deptford .. } \\
\text { Finsbury .. } \\
\text { Fulham . } \\
\text { Greenwich } \\
\text { Hackney .. } \\
\text { Hammersmith } \\
\text { Hampstead } \\
\text { Holborn .. } \\
\text { Islington .. } \\
\text { Kensington } \\
\text { Lambeth .. } \\
\text { Lewisham } \\
\text { Paddington } \\
\text { Poplar } \\
\text { St. Marylebone } \\
\text { St. Pancras } \\
\text { Shoreditch } \\
\text { Southwark } \\
\text { Stepney .. } \\
\text { Stoke Newington } \\
\text { Wandsworth } \\
\text { Westminster } \\
\text { Woolwich }\end{array}$ & 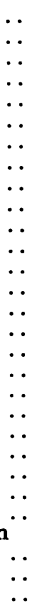 & $\begin{array}{r}27 \\
169 \\
131 \\
130 \\
259 \\
74 \\
110 \\
101 \\
137 \\
96 \\
219 \\
112 \\
82 \\
59 \\
335 \\
177 \\
302 \\
127 \\
144 \\
169 \\
133 \\
235 \\
119 \\
206 \\
299 \\
51 \\
232 \\
183 \\
117\end{array}$ & $\begin{array}{r}20 \\
168 \\
126 \\
128 \\
261 \\
66 \\
109 \\
88 \\
153 \\
96 \\
223 \\
122 \\
85 \\
49 \\
327 \\
172 \\
298 \\
161 \\
143 \\
162 \\
118 \\
218 \\
111 \\
192 \\
280 \\
51 \\
311 \\
160 \\
121\end{array}$ & $\begin{array}{r}14 \\
168 \\
119 \\
117 \\
267 \\
64 \\
113 \\
76 \\
158 \\
100 \\
222 \\
130 \\
86 \\
43 \\
331 \\
176 \\
303 \\
174 \\
144 \\
163 \\
104 \\
211 \\
104 \\
184 \\
250 \\
52 \\
328 \\
142 \\
140\end{array}$ & $\begin{array}{r}11 \\
160 \\
112 \\
108 \\
251 \\
59 \\
107 \\
70 \\
151 \\
101 \\
215 \\
136 \\
89 \\
39 \\
322 \\
181 \\
296 \\
220 \\
145 \\
155 \\
98 \\
198 \\
97 \\
172 \\
225 \\
51 \\
353 \\
130 \\
147\end{array}$ & $\begin{array}{r}5 \\
117 \\
61 \\
58 \\
179 \\
51 \\
75 \\
35 \\
122 \\
90 \\
171 \\
119 \\
95 \\
25 \\
236 \\
168 \\
230 \\
228 \\
125 \\
74 \\
76 \\
138 \\
45 \\
97 \\
99 \\
49 \\
330 \\
99 \\
148\end{array}$ & 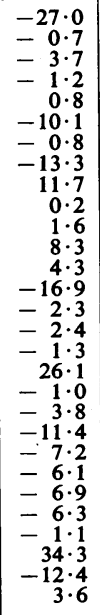 & 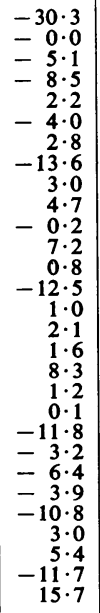 & 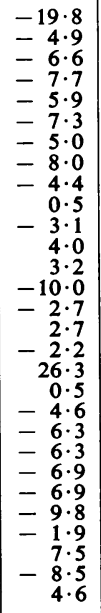 & $\begin{array}{r}-51 \cdot 6 \\
-26 \cdot 6 \\
-45 \cdot 6 \\
-46 \cdot 1 \\
-28 \cdot 5 \\
-13 \cdot 7 \\
-29 \cdot 4 \\
-49 \cdot 4 \\
-19 \cdot 1 \\
-11 \cdot 0 \\
-20 \cdot 4 \\
-11 \cdot 9 \\
7 \cdot 0 \\
-36 \cdot 2 \\
-26 \cdot 8 \\
-6 \cdot 9 \\
-22 \cdot 3 \\
3.5 \\
-13 \cdot 4 \\
-52 \cdot 6 \\
-22 \cdot 3 \\
-30 \cdot 2 \\
-53 \cdot 8 \\
-43 \cdot 4 \\
-56 \cdot 1 \\
-4 \cdot 0 \\
-6 \cdot 4 \\
-23 \cdot 6 \\
0.7\end{array}$ & $\begin{array}{l}51 \cdot 4 \\
48 \cdot 4 \\
49 \cdot 8 \\
48 \cdot 9 \\
47 \cdot 4 \\
44 \cdot 4 \\
48 \cdot 6 \\
49 \cdot 2 \\
47 \cdot 1 \\
49 \cdot 7 \\
46 \cdot 1 \\
47 \cdot 0 \\
38 \cdot 7 \\
49 \cdot 6 \\
47 \cdot 6 \\
39 \cdot 1 \\
47 \cdot 3 \\
44 \cdot 5 \\
42 \cdot 8 \\
50 \cdot 2 \\
43 \cdot 4 \\
48 \cdot 6 \\
49 \cdot 0 \\
50 \cdot 1 \\
50 \cdot 4 \\
44 \cdot 1 \\
44 \cdot 7 \\
46 \cdot 4 \\
52 \cdot 3\end{array}$ & $\begin{array}{l}51 \cdot 3 \\
48 \cdot 2 \\
50 \cdot 0 \\
48 \cdot 9 \\
47 \cdot 5 \\
42 \cdot 9 \\
48 \cdot 4 \\
48 \cdot 5 \\
47 \cdot 4 \\
49 \cdot 2 \\
46 \cdot 3 \\
47 \cdot 8 \\
38 \cdot 4 \\
48 \cdot 8 \\
47 \cdot 6 \\
38 \cdot 6 \\
47 \cdot 7 \\
45 \cdot 3 \\
42 \cdot 4 \\
49 \cdot 8 \\
42 \cdot 0 \\
48 \cdot 9 \\
49 \cdot 2 \\
49 \cdot 8 \\
50 \cdot 1 \\
44 \cdot 7 \\
45 \cdot 2 \\
45 \cdot 8 \\
50 \cdot 5\end{array}$ & $\begin{array}{l}49 \cdot 0 \\
46 \cdot 9 \\
48 \cdot 8 \\
48 \cdot 4 \\
47 \cdot 0 \\
40 \cdot 5 \\
48 \cdot 1 \\
47 \cdot 6 \\
46 \cdot 4 \\
48 \cdot 6 \\
45 \cdot 9 \\
48 \cdot 0 \\
38 \cdot 6 \\
48 \cdot 0 \\
46 \cdot 8 \\
38 \cdot 6 \\
46 \cdot 7 \\
45 \cdot 4 \\
41 \cdot 9 \\
49 \cdot 5 \\
39 \cdot 4 \\
47 \cdot 1 \\
48 \cdot 3 \\
48 \cdot 6 \\
49 \cdot 1 \\
45 \cdot 0 \\
44 \cdot 8 \\
43 \cdot 4 \\
49 \cdot 6\end{array}$ & $\begin{array}{l}50 \cdot 7 \\
47 \cdot 3 \\
49 \cdot 2 \\
48 \cdot 3 \\
47 \cdot 2 \\
40 \cdot 6 \\
48 \cdot 3 \\
48 \cdot 1 \\
46 \cdot 7 \\
49 \cdot 1 \\
46 \cdot 3 \\
48 \cdot 0 \\
39 \cdot 3 \\
46 \cdot 8 \\
47 \cdot 2 \\
39 \cdot 3 \\
47 \cdot 2 \\
46 \cdot 3 \\
42 \cdot 4 \\
49 \cdot 4 \\
39 \cdot 7 \\
47 \cdot 6 \\
48 \cdot 7 \\
49 \cdot 3 \\
48 \cdot 9 \\
45 \cdot 0 \\
45 \cdot 2 \\
43 \cdot 6 \\
49 \cdot 8\end{array}$ & $\begin{array}{l}49 \cdot 7 \\
46 \cdot 8 \\
49 \cdot 2 \\
47 \cdot 3 \\
47 \cdot 1 \\
41 \cdot 6 \\
47 \cdot 1 \\
47 \cdot 8 \\
46 \cdot 4 \\
48 \cdot 7 \\
47 \cdot 2 \\
47 \cdot 9 \\
41 \cdot 8 \\
45 \cdot 4 \\
47 \cdot 2 \\
42 \cdot 9 \\
47 \cdot 6 \\
46 \cdot 9 \\
45 \cdot 7 \\
49 \cdot 2 \\
41 \cdot 7 \\
47 \cdot 8 \\
48 \cdot 2 \\
48 \cdot 7 \\
49 \cdot 4 \\
47 \cdot 6 \\
45 \cdot 8 \\
46 \cdot 4 \\
48 \cdot 9\end{array}$ \\
\hline London & . & 4,536 & 4,522 & 4,485 & 4,397 & 3,348 & $-0 \cdot 3$ & $-0 \cdot 8$ & $-2 \cdot 0$ & $-23 \cdot 9$ & $47 \cdot 2$ & $47 \cdot 0$ & $46 \cdot 2$ & $46 \cdot 5$ & $46 \cdot 8$ \\
\hline
\end{tabular}


TABLE II

DENSITY INDICES OF BOROUGHS

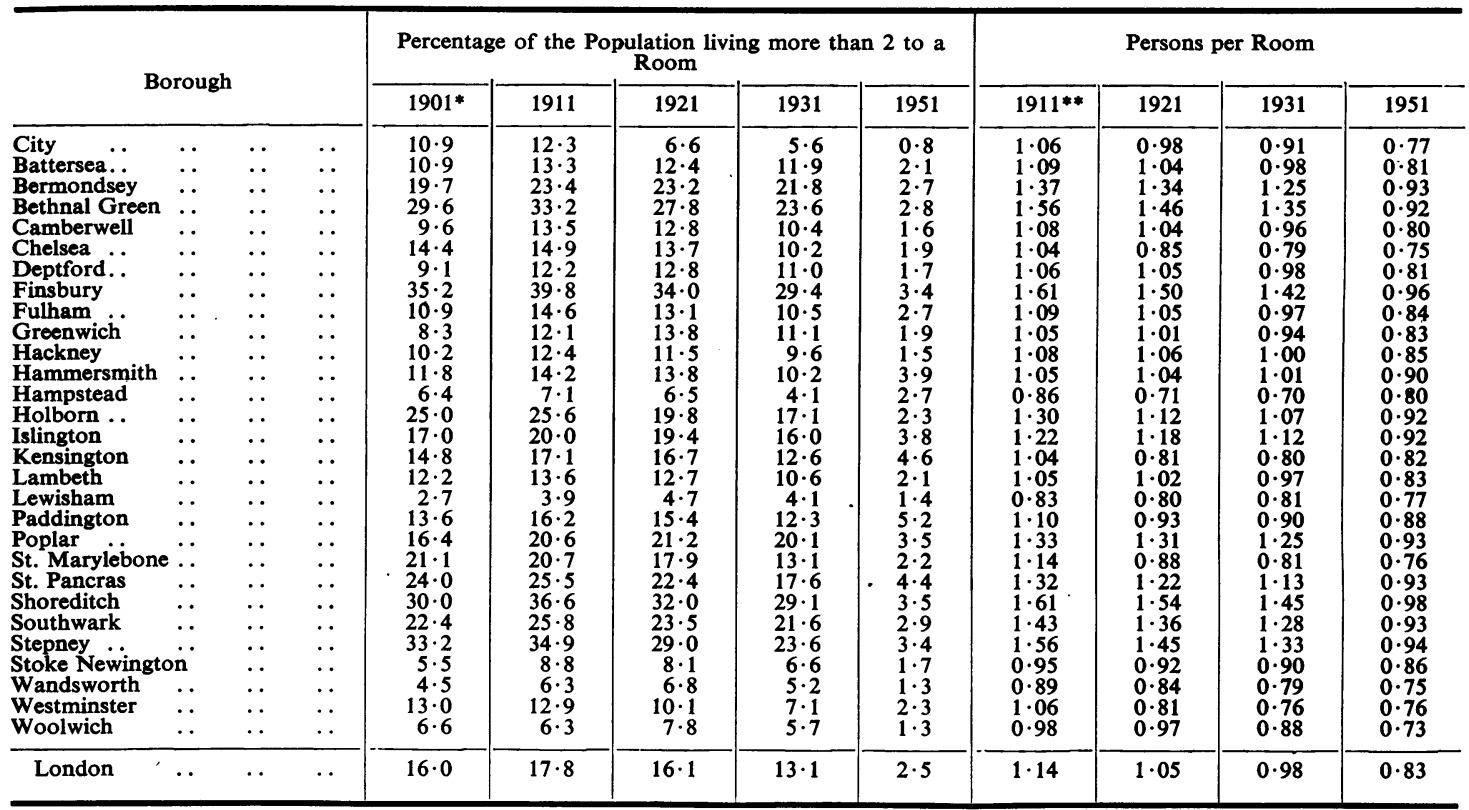

* In this year the index is of persons living more than 2 to a room in tenements of less than 5 rooms as a percentage of the total population, and consequently the value is slightly lower than it would have been on the basis of subsequent years.

** For 1911 the rate was based on families living in 1-9 rooms and is therefore slightly more than a rate based on all private families as in the other years.

Bethnal Green, Greenwich, Poplar, Shoreditch, Southwark, Stepney, and Woolwich had high male ratios in each census year.

\section{DENSITY}

Two measures of density are given in Table II. The most striking feature is the very great decrease in overcrowding that was accomplished by 1951 . Between 1911 and 1931 a small improvement had taken place in the overcrowding indices but no - large changes occurred in the relative positions of the boroughs; the boroughs with the most overcrowding in 1911 still had the most in 1931. In 1951 , in most boroughs, the proportion living more than two to a room had become only a fraction of the corresponding proportion in 1931. The lowest indices of overcrowding were recorded at each Census for the boroughs of Hampstead, Lewisham, Stoke Newington, Wandsworth, and Woolwich.

\section{Foreign-BORN POPUlation}

For the first 30 years of the 20th century the foreign-born population of London remained almost constant in proportion (some 3 per cent.). In 1951 the proportion rose to 5 per cent. and became more widely dispersed through London (Table III, opposite).

Thus, early in the century, there were two distinct colonies. One was in the Soho district, partly in Holborn and partly in Westminster, and was mainly Italian, French, and German. The other was in Stepney and consisted mainly of persons born in Russia, or Russian Poland, who formed about $\mathbf{8 0}$ per cent. of the foreign-born population in Stepney. By 1951 the Russians and Poles had overflowed into the neighbouring boroughs and formed two-thirds of the large foreign-born population of Hackney. Political refugees from Poland and Germany formed a large proportion of the increase in the foreignborn population recorded at the 1951 Census. Thus, Germans and Poles form the largest groups of foreign-born persons in the adjacent boroughs of Hampstead, Kensington, Paddington, and St. Marylebone. In 1951 the absolute number of foreign-born persons in these areas taken together was four times the figure of 1901, and formed $34 \cdot 5$ per cent. of the total foreign-born population of London compared with $11 \cdot 3$ per cent. in 1901 . In Hampstead in 1951 one person in six was of nonBritish birth. 
TABLE III

NUMBER OF FOREIGN-BORN PERSONS ENUMERATED AT EACH CENSUS AND THEIR PERCENTAGE OF TOTAL POPULATION IN EACH AREA

\begin{tabular}{|c|c|c|c|c|c|c|c|c|c|c|c|}
\hline \multirow{2}{*}{\multicolumn{2}{|c|}{ Borough }} & \multicolumn{2}{|c|}{1901} & \multicolumn{2}{|c|}{1911} & \multicolumn{2}{|c|}{1921} & \multicolumn{2}{|c|}{1931} & \multicolumn{2}{|c|}{1951} \\
\hline & & No. & Per cent. & No. & Per cent. & No. & Per cent. & No. & Per cent. & No. & Per cent. \\
\hline 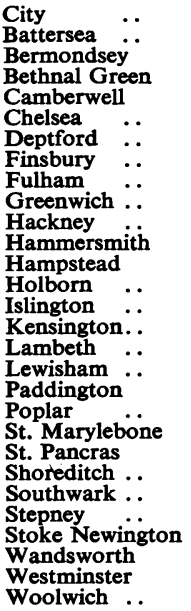 & 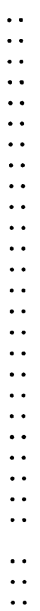 & $\begin{array}{r}1,243 \\
952 \\
1,133 \\
4,634 \\
1,494 \\
1,263 \\
742 \\
2,467 \\
1,778 \\
790 \\
3,201 \\
1,568 \\
2,269 \\
5,706 \\
4,300 \\
4,669 \\
3,506 \\
1,082 \\
2,822 \\
2,104 \\
5,560 \\
8,156 \\
2,625 \\
1,593 \\
54,310 \\
1,073 \\
2,065 \\
11,831 \\
441\end{array}$ & $\begin{array}{l}4 \cdot 6 \\
0 \cdot 6 \\
0 \cdot 9 \\
3 \cdot 6 \\
0 \cdot 6 \\
1 \cdot 7 \\
0 \cdot 7 \\
2 \cdot 4 \\
1 \cdot 3 \\
0 \cdot 8 \\
1 \cdot 5 \\
1 \cdot 4 \\
2 \cdot 8 \\
9 \cdot 6 \\
1 \cdot 3 \\
2 \cdot 6 \\
1 \cdot 2 \\
0 \cdot 8 \\
2 \cdot 0 \\
1 \cdot 2 \\
4 \cdot 2 \\
3 \cdot 5 \\
2 \cdot 2 \\
0 \cdot 8 \\
18 \cdot 2 \\
2 \cdot 1 \\
0 \cdot 9 \\
6 \cdot 5 \\
0 \cdot 4\end{array}$ & $\begin{array}{r}1,049 \\
1,129 \\
983 \\
7,791 \\
1,723 \\
1,553 \\
577 \\
2,442 \\
2,273 \\
765 \\
4,788 \\
3,152 \\
3,219 \\
5,223 \\
5,076 \\
6,534 \\
5,192 \\
1,264 \\
4,523 \\
1,966 \\
6,274 \\
10,476 \\
2,018 \\
1,766 \\
53,060 \\
1,563 \\
3,090 \\
13,047 \\
612\end{array}$ & $\begin{array}{r}5 \cdot 3 \\
0 \cdot 7 \\
0 \cdot 8 \\
6 \cdot 1 \\
0 \cdot 7 \\
2 \cdot 3 \\
0 \cdot 5 \\
2 \cdot 8 \\
1 \cdot 5 \\
0 \cdot 8 \\
2 \cdot 2 \\
2 \cdot 6 \\
3 \cdot 8 \\
10 \cdot 6 \\
1 \cdot 6 \\
3 \cdot 8 \\
1 \cdot 7 \\
0 \cdot 8 \\
3 \cdot 2 \\
1 \cdot 2 \\
5 \cdot 3 \\
4 \cdot 8 \\
1 \cdot 8 \\
0.9 \\
19 \cdot 0 \\
3 \cdot 1 \\
1 \cdot 0 \\
8 \cdot 1 \\
0 \cdot 5\end{array}$ & $\begin{array}{r}738 \\
1,291 \\
897 \\
6,864 \\
1,920 \\
1,760 \\
588 \\
1,966 \\
2,343 \\
783 \\
8,273 \\
2,870 \\
4,619 \\
4,652 \\
5,120 \\
8,469 \\
5,506 \\
1,536 \\
5,344 \\
2,517 \\
5,998 \\
9,066 \\
1,745 \\
1,744 \\
41,017 \\
2,061 \\
4,261 \\
12,318 \\
816\end{array}$ & $\begin{array}{r}5 \cdot 4 \\
0 \cdot 8 \\
0 \cdot 8 \\
5 \cdot 9 \\
0 \cdot 7 \\
2 \cdot 8 \\
0 \cdot 5 \\
2 \cdot 6 \\
1 \cdot 5 \\
0 \cdot 8 \\
3 \cdot 7 \\
2 \cdot 2 \\
5 \cdot 4 \\
10 \cdot 4 \\
1 \cdot 5 \\
4 \cdot 8 \\
1 \cdot 8 \\
0.9 \\
3 \cdot 7 \\
1 \cdot 5 \\
5 \cdot 8 \\
4 \cdot 3 \\
1 \cdot 7 \\
0 \cdot 9 \\
16 \cdot 4 \\
4 \cdot 0 \\
1 \cdot 3 \\
8 \cdot 7 \\
0 \cdot 6\end{array}$ & $\begin{array}{r}567 \\
1,214 \\
804 \\
5,356 \\
1,828 \\
1,551 \\
620 \\
1,564 \\
2,195 \\
839 \\
10,291 \\
2,430 \\
5,691 \\
3,521 \\
5,050 \\
8,214 \\
4,738 \\
1,704 \\
5,298 \\
1,666 \\
5,179 \\
7,267 \\
1,556 \\
1,352 \\
30,083 \\
2,712 \\
9,455 \\
9,229 \\
902\end{array}$ & $\begin{array}{l}5 \cdot 2 \\
0 \cdot 8 \\
0 \cdot 7 \\
5 \cdot 0 \\
0 \cdot 7 \\
2 \cdot 6 \\
0 \cdot 6 \\
2 \cdot 2 \\
1 \cdot 5 \\
0 \cdot 8 \\
4 \cdot 8 \\
1 \cdot 8 \\
6 \cdot 4 \\
9 \cdot 1 \\
1 \cdot 6 \\
4 \cdot 5 \\
1 \cdot 6 \\
0 \cdot 8 \\
3 \cdot 7 \\
1 \cdot 1 \\
5 \cdot 3 \\
3 \cdot 7 \\
1 \cdot 6 \\
0 \cdot 8 \\
13 \cdot 4 \\
5 \cdot 3 \\
2 \cdot 7 \\
7 \cdot 1 \\
0.6\end{array}$ & $\begin{array}{r}197 \\
2,689 \\
818 \\
1,951 \\
3,509 \\
4,033 \\
1,083 \\
1,124 \\
4,916 \\
1,387 \\
12,639 \\
4,817 \\
15,650 \\
2,094 \\
7,502 \\
19,871 \\
7,517 \\
3,393 \\
12,741 \\
1,320 \\
8,872 \\
7,899 \\
847 \\
1,751 \\
8,503 \\
3,883 \\
13,567 \\
9,401 \\
1,811\end{array}$ & $\begin{array}{r}3 \cdot 7 \\
2 \cdot 3 \\
1 \cdot 3 \\
3 \cdot 3 \\
2 \cdot 0 \\
7 \cdot 9 \\
1 \cdot 4 \\
3 \cdot 2 \\
4 \cdot 0 \\
1 \cdot 5 \\
7 \cdot 4 \\
4 \cdot 0 \\
16 \cdot 5 \\
8 \cdot 4 \\
3 \cdot 2 \\
11 \cdot 8 \\
3 \cdot 3 \\
1 \cdot 5 \\
10 \cdot 2 \\
1 \cdot 8 \\
11 \cdot 7 \\
5 \cdot 7 \\
1 \cdot 9 \\
1 \cdot 8 \\
8 \cdot 6 \\
7 \cdot 9 \\
4 \cdot 1 \\
9 \cdot 5 \\
1 \cdot 2\end{array}$ \\
\hline London & .. & 135,377 & $3 \cdot 0$ & 153,128 & $3 \cdot 4$ & 147,082 & $3 \cdot 3$ & 132,876 & $3 \cdot 0$ & 165,785 & $5 \cdot 0$ \\
\hline
\end{tabular}

TABLE IIIA

FOREIGN-BORN RESIDENTS BY NATIONALITY

\begin{tabular}{|c|c|c|c|c|c|c|}
\hline \multirow{2}{*}{\multicolumn{2}{|c|}{ Country of Origin }} & \multicolumn{5}{|c|}{ Percentage of all Foreign-born in London } \\
\hline & & 1901 & 1911 & 1921 & 1931 & 1951 \\
\hline $\begin{array}{l}\text { Russia } \\
\text { Poland } \\
\text { Germany } \\
\text { France } \\
\text { Italy } \\
\text { Austria } \\
\text { Others }\end{array}$ & $\begin{array}{l}\cdots \\
\cdots \\
\cdots \\
\cdots \\
\cdots\end{array}$ & $\begin{array}{r}39 \cdot 5 \\
20 \cdot 3 \\
8 \cdot 3 \\
8 \cdot 0 \\
4 \cdot 6 \\
19 \cdot 3\end{array}$ & $\begin{array}{r}41 \cdot 2 \\
17 \cdot 8 \\
9 \cdot 0 \\
7 \cdot 6 \\
5 \cdot 3 \\
19 \cdot 1\end{array}$ & $\begin{array}{r}23 \cdot 8 \\
21 \cdot 1 \\
6 \cdot 2 \\
9 \cdot 7 \\
8 \cdot 0 \\
1 \cdot 1 \\
30 \cdot 1\end{array}$ & $\begin{array}{r}15 \cdot 4 \\
22 \cdot 5 \\
7 \cdot 4 \\
7 \cdot 9 \\
8 \cdot 1 \\
1 \cdot 5 \\
37 \cdot 2\end{array}$ & $\begin{array}{r}11 \cdot 7 \\
23 \cdot 9 \\
13 \cdot 2 \\
5.9 \\
7 \cdot 0 \\
7 \cdot 0 \\
31 \cdot 3\end{array}$ \\
\hline Total . & $\ldots$ & 100 & 100 & 100 & 100 & 100 \\
\hline
\end{tabular}

Death Rates

Before the adoption in 1911 of the method of transference of deaths to place of usual residence, the death rates in the London boroughs were affected by the number of hospitals and institutions within their boundaries, deaths occurring in such institutions being credited to the borough in which the institution was situated. The study of mortality has therefore been limited to the years 1911 onwards. Some method of standardization is necessary for comparing the London boroughs owing to the varying sex and age constitutions of the populations. For this purpose the direct method of standardization has been used, with the census population of London in 1931 as the standard population. The standardized death rates calculated on this basis are shown in Table IV, which shows that considerable variation in the death rate between London boroughs was present in each period. The range between the boroughs decreased slightly, however; the ratio of the highest to the lowest was 1.8 in 1911-13 and 1.4 in 1950-52. The boroughs of Hampstead, Lewisham,

TABLE IV

STANDARDIZED DEATH RATES

\begin{tabular}{|c|c|c|c|c|c|c|}
\hline \multicolumn{3}{|c|}{ Borough } & $1911-13$ & $1920-22$ & $1930-32$ & $1950-52$ \\
\hline $\begin{array}{l}\text { City } \\
\text { Battersea } \\
\text { Bermondsey } \\
\text { Bethnal Green } \\
\text { Camberwell } \\
\text { Chelsea } \\
\text { Deptford } \\
\text { Finsbury } \\
\text { Fulham } \\
\text { Greenwich } \\
\text { Hackney } \\
\text { Hammersmith } \\
\text { Hampstead } \\
\text { Holborn } \\
\text { Islington } \\
\text { Kensington } \\
\text { Lambeth } \\
\text { Lewisham } \\
\text { Paddington } \\
\text { Poplar } \\
\text { St. Marylebon } \\
\text { St. Pancras } \\
\text { Shoreditch } \\
\text { Southwark } \\
\text { Stepney } \\
\text { Stoke Newing } \\
\text { Wandsworth } \\
\text { Westminster } \\
\text { Woolwich }\end{array}$ & 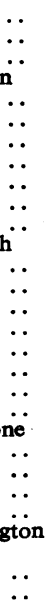 & 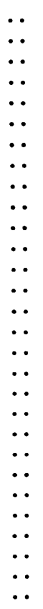 & $\begin{array}{l}19 \cdot 45 \\
15 \cdot 29 \\
20 \cdot 31 \\
18 \cdot 86 \\
15 \cdot 11 \\
14 \cdot 25 \\
16 \cdot 89 \\
21 \cdot 90 \\
16 \cdot 20 \\
14 \cdot 92 \\
14 \cdot 85 \\
15 \cdot 78 \\
12 \cdot 35 \\
17 \cdot 71 \\
16 \cdot 03 \\
14 \cdot 97 \\
15 \cdot 51 \\
12 \cdot 09 \\
14 \cdot 47 \\
18 \cdot 26 \\
16 \cdot 29 \\
16 \cdot 82 \\
19 \cdot 51 \\
19 \cdot 68 \\
18 \cdot 87 \\
13 \cdot 98 \\
12 \cdot 57 \\
15 \cdot 72 \\
14 \cdot 78\end{array}$ & $\begin{array}{l}15 \cdot 42 \\
13 \cdot 56 \\
16 \cdot 84 \\
16 \cdot 39 \\
13 \cdot 57 \\
12 \cdot 09 \\
14 \cdot 21 \\
17 \cdot 61 \\
13 \cdot 09 \\
13 \cdot 46 \\
13 \cdot 47 \\
13 \cdot 65 \\
11 \cdot 32 \\
15 \cdot 55 \\
14 \cdot 27 \\
13 \cdot 58 \\
13 \cdot 72 \\
11 \cdot 14 \\
12 \cdot 92 \\
15 \cdot 21 \\
14 \cdot 27 \\
14 \cdot 77 \\
16 \cdot 33 \\
16 \cdot 41 \\
16 \cdot 53 \\
13 \cdot 42 \\
11 \cdot 49 \\
13 \cdot 47 \\
12 \cdot 42\end{array}$ & $\begin{array}{l}13 \cdot 10 \\
11 \cdot 53 \\
14 \cdot 04 \\
13 \cdot 18 \\
11 \cdot 45 \\
11 \cdot 35 \\
12 \cdot 04 \\
14 \cdot 51 \\
11 \cdot 80 \\
11 \cdot 17 \\
11 \cdot 70 \\
12 \cdot 32 \\
10 \cdot 68 \\
13 \cdot 50 \\
12 \cdot 37 \\
12 \cdot 50 \\
11 \cdot 99 \\
9 \cdot 93 \\
12 \cdot 61 \\
12 \cdot 74 \\
12 \cdot 36 \\
12 \cdot 78 \\
13 \cdot 22 \\
13 \cdot 99 \\
14 \cdot 35 \\
11 \cdot 92 \\
10 \cdot 27 \\
12 \cdot 12 \\
11 \cdot 53\end{array}$ & $\begin{array}{r}8 \cdot 05 \\
8 \cdot 56 \\
9 \cdot 68 \\
9 \cdot 69 \\
8 \cdot 97 \\
8 \cdot 63 \\
9 \cdot 11 \\
9 \cdot 77 \\
8 \cdot 69 \\
8 \cdot 60 \\
8 \cdot 90 \\
9 \cdot 05 \\
7 \cdot 80 \\
8 \cdot 86 \\
9 \cdot 07 \\
8 \cdot 49 \\
9 \cdot 05 \\
8 \cdot 08 \\
8 \cdot 92 \\
9 \cdot 78 \\
8 \cdot 67 \\
9 \cdot 12 \\
9 \cdot 69 \\
10 \cdot 10 \\
10 \cdot 65 \\
9 \cdot 16 \\
8 \cdot 08 \\
8 \cdot 34 \\
8 \cdot 44\end{array}$ \\
\hline London & .. & .. & $15 \cdot 98$ & $13 \cdot 91$ & $12 \cdot 05$ & $8 \cdot 77$ \\
\hline
\end{tabular}


and Wandsworth had the lowest death rates throughout the 40 years, and the boroughs of Bermondsey, Bethnal Green, Finsbury, Shoreditch, Southwark, and Stepney the highest. As is well known, the fall in the death rate has been largely due to the fall in infant and child mortality. This can be illustrated by considering the death rates for the first and last period for London as a whole (Table V):

TABLE V

ADMINISTRATIVE COUNTY OF LONDON DEATH RATES PER 1,000

\begin{tabular}{|c|c|c|c|c|}
\hline \multirow{2}{*}{ Age (yrs) } & \multicolumn{2}{|c|}{$1911-13$} & \multicolumn{2}{|c|}{$1950-52$} \\
\hline & Males & Females & Males & Females \\
\hline $\begin{array}{c}0- \\
5- \\
15- \\
25- \\
45- \\
65- \\
75+\end{array}$ & $\begin{array}{r}43 \cdot 0 \\
2 \cdot 7 \\
3 \cdot 2 \\
7 \cdot 3 \\
24 \cdot 6 \\
68 \cdot 2 \\
158 \cdot 6\end{array}$ & $\begin{array}{r}36 \cdot 3 \\
2 \cdot 6 \\
2 \cdot 5 \\
5 \cdot 1 \\
17 \cdot 2 \\
51 \cdot 5 \\
135 \cdot 8\end{array}$ & $\begin{array}{r}6 \cdot 4 \\
0 \cdot 6 \\
0 \cdot 9 \\
2 \cdot 2 \\
16 \cdot 4 \\
61 \cdot 5 \\
152 \cdot 7\end{array}$ & $\begin{array}{r}4 \cdot 9 \\
0 \cdot 4 \\
0 \cdot 6 \\
1 \cdot 7 \\
8 \cdot 5 \\
32 \cdot 5 \\
115 \cdot 3\end{array}$ \\
\hline
\end{tabular}

It will be noted that between the ages of 45 and 74 the female death rate has decreased faster than the male rate. The death rate for most causes of death in these two age groups show a female advantage. For three large and important groups of causes the rates in 1951 were as shown in Table VI.

TABLE VI

DEATH RATES FOR CERTAIN CAUSES FOR AGES 45 AND OVER

\begin{tabular}{c|cc|c|c|c}
\hline \multicolumn{2}{c|}{ Cause of Death } & & Cancer & $\begin{array}{c}\text { Heart } \\
\text { Diseases }\end{array}$ & $\begin{array}{c}\text { Bron- } \\
\text { chitis }\end{array}$ \\
\hline \multirow{2}{*}{ Age 45-64 } & Males .. & $\ldots$ & $4 \cdot 3$ & $4 \cdot 4$ & $1 \cdot 9$ \\
\cline { 2 - 6 } & Females & $\ldots$ & $2 \cdot 7$ & $1 \cdot 8$ & $0 \cdot 4$ \\
\hline \multirow{2}{*}{ Age 65-74 } & Males . & $\ldots$ & $13 \cdot 5$ & $20 \cdot 4$ & $8 \cdot 4$ \\
\cline { 2 - 6 } & Females & $\ldots$ & $6 \cdot 6$ & $11 \cdot 1$ & $2 \cdot 5$ \\
\hline
\end{tabular}

Since the overcrowding indices had been so drastically reduced by 1951 it seems of interest to see whether, as in the past, the indices of living condiditions are correlated with the death rate. Excluding the City of London from the calculations, the correlation coefficients between the socio-economic conditions of the boroughs and their standardized deaths rates are as follows:

\begin{tabular}{l|l|c|c|c|c}
\hline & Correlations & $\begin{array}{r}1911-13 \\
r\end{array}$ & $1920-22$ & $\begin{array}{c}1930-32 \\
r\end{array}$ & $1950-52$ \\
\hline & $\begin{array}{l}\text { Percentage living more } \\
\text { than two to a room }\end{array}$ & 0.889 & 0.922 & 0.874 & 0.364 \\
\hline $\begin{array}{l}\text { Standar- } \\
\text { dized } \\
\text { Death } \\
\text { Rate } \\
\text { and }\end{array}$ & $\begin{array}{l}\text { Persons per Room } \\
\text { Proportion of popula- } \\
\text { tion in Social Classes } \\
\text { IV and V . }\end{array}$ & 0.930 & 0.906 & 0.799 & 0.800 \\
\hline
\end{tabular}

5 per cent level of significance $r=0 \cdot 36,1$ per cent. level $r=0 \cdot 46$.
The death rate was highly correlated with the percentage of persons living more than two to a room in the first three periods, but the coefficient had only just reached the 5 per cent. level of significance in 1950-52. On the other hand the death rate and persons per room was the same for the last two triennia and only slightly below the earlier figures. The correlation between the death rate and the proportion of the male population in Social Classes IV and $\mathrm{V}$ was significant for each of the three triennia for which this index was available and significantly larger in 1950-52 than in the earlier periods.

\section{Birth Rate}

Heron (1906), from a study of the data relating to the London Boroughs, found a negative correlation between fertility and social status. Some of the indices used were approximate, but Mitra (1937) extended the analysis to include data for the 1931 census, with its more accurate index of social conditions, and substantially confirmed Heron's conclusions. The crude birth rate is influenced by the sex and age constitution of the population, and for this reason the legitimate births per 1,000 married women aged 15-44 have been used in the present study (Table VII).

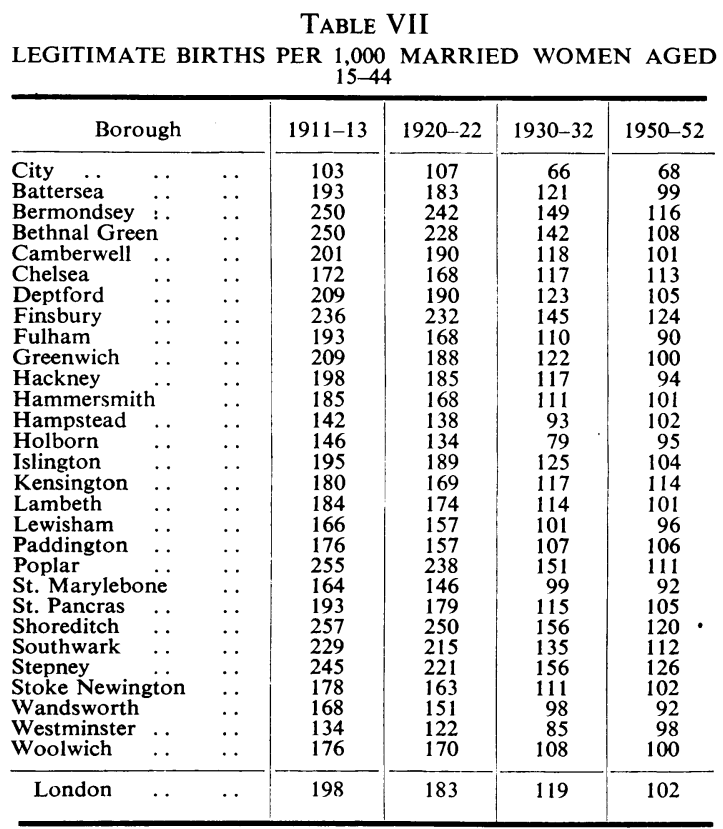

The highest birth rates were in the East End boroughs throughout the period, while the lowest were those of Hampstead, Holborn, and Westminster in the first three triennia, and of Fulham, St. 
Marylebone, and Wandsworth in 1950-52. A comparison of Table VII with Tables II and III suggests that the birth rate, like the death rate, is correlated with the density indices. The correlations are:

\begin{tabular}{|c|c|c|c|c|c|}
\hline \multicolumn{2}{|r|}{ Correlations } & $\underset{r}{1911-13}$ & $\underset{r}{1920-22}$ & $\stackrel{1930-32}{r}$ & $\underset{r}{1950-52}$ \\
\hline \multirow{4}{*}{$\begin{array}{l}\text { Legiti- } \\
\text { mate } \\
\text { Birth } \\
\text { Rate } \\
\text { and }\end{array}$} & $\begin{array}{c}\text { Standardized } \\
\text { Rate }\end{array}$ & $0 \cdot 748$ & $0 \cdot 741$ & 0.588 & 0.718 \\
\hline & $\begin{array}{c}\text { Percentage living more } \\
\text { than Two to a Room }\end{array}$ & 0.666 & 0.750 & 0.777 & 0.491 \\
\hline & Persons per Room & 0.768 & 0.876 & 0.825 & 0.601 \\
\hline & $\begin{array}{l}\text { Proportion of popula- } \\
\text { tion in Social Classes } \\
\text { IV and } \mathrm{V} \ldots\end{array}$ & - & $0 \cdot 811$ & 0.776 & 0.670 \\
\hline
\end{tabular}

All the correlations are significant. The indices of density in 1950-52 were not so highly correlated with the birth rate as in former years, and the correlation between birth rate and the proportion in the lowest social classes of the population has also decreased since 1920-22, though the difference between 0.811 and 0.670 is not significant.

\section{INFANT MORTALITY}

Hersch (1943) chose infant mortality as the best single numerical index of the degree of civilization of a population. He considered that a decrease in this rate reflected the advances made in hygiene, medicine, chemistry, and public instruction, and that it was the best sign of improved living conditions. When Hersch was writing infant mortality in Europe ranged from 37 in the Netherlands to 180 in Rumania, and even higher rates occurred in Eastern countries.

In England and Wales infant mortality has been used in the past as an index of the socio-economic level of the community, since the highest rates were found to occur where living conditions were worst, and infant mortality varied directly with social class. McKinlay (1928) attempted to standardize for varying social conditions in the London boroughs, but found that such standardization for economic status did not reduce the variability between the boroughs by as much as seemed $a$ priori probable. Stocks (1928), using the occupations of the males from the census returns, attempted to find a correction factor which would reflect the social make-up of the London boroughs. This correction, however, only reduced the variability between the infant mortality rates of the London boroughs from 17 to 14 per cent. in 1911-13, and from 15 to 13 per cent. in 1921-25. The findings of McKinlay and Stocks are in agreement, and clearly the economic factor, as measured by their indices, was not very important in determining the level of infant mortality in the various boroughs. During the past 25 years the effect of many variables has been studied: e.g. indices of density, proportion of mothers employed, fertility rate, and proportion of males in the professional classes and in the lowest type of labour, etc. These investigations have shown that infant mortality was affected by socio-economic conditions, but since the variables used were themselves inter-related it has not been possible to assess the relative importance of their contributions. In recent years infant mortality has fallen rapidly. In England and Wales the rate was 154 deaths per 1,000 live births in 1900, by 1922 , this had been halved, and in 1930 the rate was down to 60. Between 1930 and 1941 the rate fluctuated between 51 and 66, but since 1941 when it was 60 it has fallen steadily to $25 \cdot 5$ in 1954 .

In 1950-52 the infant mortality rate for London (24) was below the rate for the whole country (29), and much below the rates for the county boroughs of Durham (40), Lancashire (36), Staffordshire (34), and Yorkshire West Riding (31). Not only was the infant mortality lower in London than in the large industrial towns of the north but the range was smaller; thus the rates in 1950-52 ranged from 19 to 31 in the 28 London boroughs, from 29 to 47 in the seventeen country boroughs of Lancashire, and from 23 to 38 in the eleven county boroughs of Yorkshire West Riding. The low level and relatively small range of infant mortality make the London boroughs unrepresentative of urban areas in general. Use of the 1931 census data showed that, although the infant mortality by social class in London showed the same progression as in the whole of the country, the usual indices of social structure in urban areas were less highly correlated with infant mortality than formerly. It was reasonable to suppose that these correlations would have declined still further during recent years, although the social class differential would still exist. No data, however, existed to test this hypothesis until the publication of the 1951 census for London. The occupational supplement is not yet published and it is not possible to display the infant mortality by social class, but there is no reason to suppose that the relative differences between the social classes has undergone much change. A triennial period centred in the census year was used for the appropriate rates shown in Table VIII, overleaf.

For the County of London as a whole, infant mortality in $1950-52(24$ per 1,000$)$ was less than one- 
TABLE VIII

INFANT MORTALITY

\begin{tabular}{|c|c|c|c|c|c|c|}
\hline \multicolumn{3}{|c|}{ Borough } & $1911-13$ & $1920-22$ & $1930-32$ & $1950-52$ \\
\hline $\begin{array}{l}\text { City .. } \\
\text { Battersea } \\
\text { Bermondsey } \\
\text { Bethnal Gree } \\
\text { Camberwell } \\
\text { Chelsea } \\
\text { Deptford } \\
\text { Finsbury } \\
\text { Fulham } \\
\text { Greenwich } \\
\text { Hackney } \\
\text { Hammersmit } \\
\text { Hampstead } \\
\text { Holborn } \\
\text { Islington } \\
\text { Kensington } \\
\text { Lambeth } \\
\text { Lewisham } \\
\text { Paddington } \\
\text { Poplar } \\
\text { St. Marylebor } \\
\text { St. Pancras } \\
\text { Shoreditch } \\
\text { Southwark } \\
\text { Stepney } \\
\text { Stoke Newing } \\
\text { Wandsworth } \\
\text { Westminster } \\
\text { Woolwich }\end{array}$ & 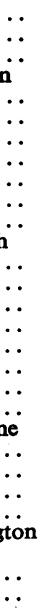 & 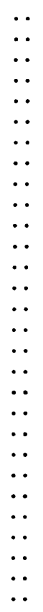 & $\begin{array}{r}95 \\
107 \\
134 \\
122 \\
100 \\
91 \\
117 \\
137 \\
105 \\
102 \\
100 \\
114 \\
72 \\
101 \\
107 . \\
112 \\
104 \\
84 \\
109 \\
126 \\
97 \\
98 \\
150 \\
122 \\
121 \\
85 \\
96 \\
95 \\
84\end{array}$ & $\begin{array}{r}80 \\
75 \\
93 \\
95 \\
74 \\
67 \\
80 \\
83 \\
76 \\
68 \\
73 \\
75 \\
57 \\
73 \\
77 \\
91 \\
74 \\
59 \\
80 \\
81 \\
69 \\
75 \\
102 \\
85 \\
86 \\
67 \\
64 \\
70 \\
62\end{array}$ & $\begin{array}{l}58 \\
57 \\
59 \\
72 \\
58 \\
45 \\
60 \\
73 \\
61 \\
65 \\
55 \\
66 \\
58 \\
78 \\
67 \\
81 \\
57 \\
49 \\
91 \\
65 \\
72 \\
66 \\
73 \\
63 \\
71 \\
54 \\
60 \\
67 \\
54\end{array}$ & $\begin{array}{l}52 \\
24 \\
21 \\
27 \\
25 \\
23 \\
28 \\
19 \\
26 \\
21 \\
24 \\
20 \\
23 \\
31 \\
27 \\
27 \\
26 \\
24 \\
28 \\
27 \\
22 \\
27 \\
25 \\
22 \\
22 \\
23 \\
22 \\
28 \\
24\end{array}$ \\
\hline London & .. & $\cdots$ & 109 & 75 & 64 & 24 \\
\hline
\end{tabular}

quarter of the rate in 1911-13 (109 per 1,000$)$. The largest falls occurred in boroughs where the rate was previously very high, the ratio of the lowest to the highest infant mortality being $2 \cdot 1$ in 1911-13 and $1 \cdot 6$ in 1950-52. The correlations with social indices exhibited by the standardized death rates and the legitimate birth rates are not apparent in these infant mortality rates. The correlations are:

\begin{tabular}{|c|c|c|c|c|c|}
\hline & Correlations & $\underset{r}{1911-13}$ & $\underset{r}{1920-22}$ & $\underset{r}{1930-32}$ & $\underset{r}{1950-52}$ \\
\hline \multirow{3}{*}{$\begin{array}{l}\text { Infant } \\
\text { Mortal- } \\
\text { ity and }\end{array}$} & $\begin{array}{l}\text { Percentage Occupied } \\
\text { Males in Social } \\
\text { Classes IV and V .. }\end{array}$ & - & 0.649 & $0 \cdot 132$ & -0.072 \\
\hline & Persons per Room & 0.823 & $0 \cdot 767$ & $0 \cdot 300$ & $0 \cdot 020$ \\
\hline & $\begin{array}{c}\text { Percentage living more } \\
\text { than Two to a Room }\end{array}$ & 0.782 & 0.812 & 0.478 & 0.184 \\
\hline
\end{tabular}

Infant mortality showed a large positive correlation with each of the three indices of social status up to 1920-22. In 1930-32 it has almost ceased to be affected by the measures of social conditions, and only the percentage living more than two to a room was significantly correlated with the rate. In 1950-52 no significant correlation was present.

The general death rate, crude or standardized, has been frequently used as a broad measure of the health of the people, and recently the birth rate has given an indirect measure of the conditions of living since it has shown a steep gradation with social class. The correlations of infant mortality with these rates for the last four census periods are:

\begin{tabular}{|c|c|c|c|c|c|}
\hline \multicolumn{2}{|r|}{ Correlations } & ${ }_{r}^{1911-13}$ & $\underset{r}{1920-22}$ & $\underset{r}{1930-32}$ & $\frac{1950-52}{r}$ \\
\hline \multirow{4}{*}{$\begin{array}{l}\text { Infant } \\
\text { Mortal- } \\
\text { ity and }\end{array}$} & Crude Death Rate .. & 0.879 & $0 \cdot 785$ & 0.523 & -0.275 \\
\hline & Crude Birth Rate & $0 \cdot 812$ & $0 \cdot 702$ & 0.043 & -0.275 \\
\hline & \begin{tabular}{ccc} 
Standardized & \multicolumn{2}{l}{ Death } \\
Rate & $\ldots$
\end{tabular} & 0.853 & 0.794 & 0.553 & $-0 \cdot 126$ \\
\hline & $\begin{array}{l}\text { Legitimate Birth Rate } \\
\text { for Women aged 15- } \\
44 \text { yrs }\end{array}$ & 0.836 & 0.754 & 0.089 & $-0 \cdot 225$ \\
\hline
\end{tabular}

In 1911-13, the correlations were all of the same order, being large and positive. In 1920-22, they were slightly smaller, but still large and significant and approximately equal. In 1930-32, the infant mortality was no longer correlated with the measures of the birth rate; the correlation with the measures of mortality had fallen considerably but was still significant. In 1950-52, no significant correlation existed at all.

From the preceding correlations it might be inferred that infant mortality has now fallen to such a low level that it is no longer any criterion of the social or economic differences between the London Eoroughs. While this is so for the death rate for the whole of the first year of life, it must be realized that the neonatal mortality is now affecting the correlation more than in former years, since the deaths in the first month of life form a much larger proportion of the infant deaths than formerly. The percentage of deaths at various ages in the first year of life in London, for the period reviewed, are shown in Table IX:

TABLE IX

DEATHS IN THE FIRST YEAR OF LIFE

\begin{tabular}{|c|c|c|c|c|c|c|}
\hline \multicolumn{3}{|c|}{ Age (mths) } & $1911-13$ & $1920-22$ & $1930-32$ & $1950-52$ \\
\hline $\begin{array}{l}\text { Under } 1 \\
1-3 \\
3-6 \\
6-12\end{array}$ & $\ddot{*}$ & $\begin{array}{l}\ddot{*} \\
\ddot{*}\end{array}$ & $\begin{array}{l}31 \cdot 7 \\
19 \cdot 1 \\
19 \cdot 4 \\
29 \cdot 8\end{array}$ & $\begin{array}{l}37 \cdot 6 \\
18 \cdot 8 \\
18 \cdot 1 \\
25 \cdot 5\end{array}$ & $\begin{array}{l}39 \cdot 2 \\
17 \cdot 1 \\
18 \cdot 4 \\
25 \cdot 3\end{array}$ & $\begin{array}{r}67 \cdot 4 \\
13 \cdot 3 \\
10 \cdot 4 \\
8 \cdot 9\end{array}$ \\
\hline Total & $\ldots$ & $\ldots$ & 100 & 100 & 100 & 100 \\
\hline
\end{tabular}

The very different structure of infant mortality in 1950-52 suggested that it would be of interest to examine the relation of infant mortality and socioeconomic indices by ages: 


\begin{tabular}{|c|c|c|c|c|}
\hline $\begin{array}{c}\text { Age } \\
\text { (mths) }\end{array}$ & Years & $\begin{array}{c}\text { Proportion of } \\
\text { Population in } \\
\text { Social Classes } \\
\text { IV and V } \\
r\end{array}$ & $\begin{array}{c}\text { Persons } \\
\text { per Room } \\
r\end{array}$ & $\begin{array}{c}\text { Percentage } \\
\text { living more } \\
\text { than two to a } \\
\text { Room } \\
r\end{array}$ \\
\hline Under 1 & $\begin{array}{l}1920-22 \\
1930-32 \\
1950-52\end{array}$ & $\begin{array}{r}0.177 \\
-0.295 \\
-0.430\end{array}$ & $\begin{array}{r}0.226 \\
-0.184 \\
-0.389\end{array}$ & $\begin{array}{r}0.350 \\
-0.187 \\
-0.118\end{array}$ \\
\hline $1-3$ & $\begin{array}{l}1920-22 \\
1930-32 \\
1950-52\end{array}$ & $\begin{array}{r}0.499 \\
-0.155 \\
0.273\end{array}$ & $\begin{array}{l}0 \cdot 618 \\
0 \cdot 027 \\
0 \cdot 319\end{array}$ & $\begin{array}{l}0.632 \\
0 \cdot 116 \\
0 \cdot 322\end{array}$ \\
\hline $3-6$ & $\begin{array}{l}1920-22 \\
1930-32 \\
1950-52\end{array}$ & $\begin{array}{l}0.541 \\
0.113 \\
0.387\end{array}$ & $\begin{array}{l}0.698 \\
0.242 \\
0.430\end{array}$ & $\begin{array}{l}0.691 \\
0.476 \\
0.328\end{array}$ \\
\hline $6-12$ & $\begin{array}{l}1920-22 \\
1930-32 \\
1950-52\end{array}$ & $\begin{array}{l}0.714 \\
0.521 \\
0.428\end{array}$ & $\begin{array}{l}0.786 \\
0.622 \\
0.288\end{array}$ & $\begin{array}{l}0 \cdot 802 \\
0.749 \\
0 \cdot 248\end{array}$ \\
\hline $1-12$ & $\begin{array}{l}1920-22 \\
1930-32 \\
1950-52\end{array}$ & $\begin{array}{l}0.667 \\
0.273 \\
0.496\end{array}$ & $\begin{array}{l}0.778 \\
0.428 \\
0.484\end{array}$ & $\begin{array}{l}0.788 \\
0.620 \\
0.414\end{array}$ \\
\hline
\end{tabular}

In the first two triennia the correlations between neonatal mortality and the indices of socio-economic conditions were not significant, but in 1950-52 the percentage of the population in Social Classes IV and $V$ and the number of persons per room showed a significant negative correlation. During the period the fall in the birth rate, from 198 legitimate births per 1,000 married women aged 15-44 in 1911-13 to 102 in 1950-52 for the whole of London, may account for this negative correlation by increasing the relative importance of the first births. Heady, Daly, and Morris (1955) showed that, for mothers aged 25 years and over, neonatal mortality is highest among first-born children and increases with age of mother. It has been shown that the birth rate is correlated with the three indices of general living conditions, i.e. the lower the social index the higher the birth rate, and it is known that the age of marriage decreases with social class. In 1920-22, the infant mortality at all later ages, 1-3 months, 3-6 months, 6-12 months, and 1-12 months, was significantly correlated with the three indices of environmental conditions. In 1930-32, the correlations at 1-3 months were all insignificant, at 3-6 months one was significant (the percentage of the population living more than two to a room), and at 6-12 months all three were significant. For the post-neonatal period as a whole (1-12 months), the correlation between infant mortality and the percentage in Social Classes IV and $\mathrm{V}$ was insignificant, but the other two correlations were significant. In 1950-52, the infant mortality at 1-3 months was not correlated with any of the indices, at 3-6 months it was significantly correlated with the percentage in Social Classes IV and V and the number of persons per room but not with the other index of overcrowding, while at 6-12 months only the percentage in Social Classes IV and V gave a significant figure. For the post-neonatal period, all three indices were significantly correlated with infant mortality.

This sub-division of infant mortality by ages shows, as expected, that the trend of the neonatal mortality is at least partially responsible for the lack of correlation in 1950-52 between infant mortality and sociol-economic conditions. The post-neonatal rate remains significantly correlated with the three indices, though probably at a lower level than in 1920-22 (the differences between the two periods are not significant, except the percentage living more than two to a room).

The relationship between the social indices and infant mortality may rest partly on the population of the boroughs. Most boroughs conform to the official description of a large town having a population of over 50,000; they were divided arbitrarily into three groups* and the correlations found between the percentage living more than two to a room and infant mortality and neonatal mortality:

\begin{tabular}{|c|c|c|c|c|c|}
\hline \multirow{3}{*}{ Population } & \multirow{3}{*}{$\begin{array}{l}\text { No. of } \\
\text { Boroughs }\end{array}$} & \multicolumn{4}{|c|}{$\begin{array}{l}\text { Percentage living more than two to } \\
\text { : Room (1951) correlated with }\end{array}$} \\
\hline & & \multicolumn{2}{|c|}{$\begin{array}{l}\text { Neonatal } \\
\text { Mortality }\end{array}$} & \multicolumn{2}{|c|}{$\begin{array}{l}\text { Infant } \\
\text { Mortality }\end{array}$} \\
\hline & & $r$ & $p$ & $r$ & $p$ \\
\hline 120,000 and Over & 11 & 0.47 & $>0 \cdot 1$ & 0.89 & $<0.01$ \\
\hline $\begin{array}{l}\text { Under } 120,000 \\
\text { Under } 60,000 \ldots\end{array}$ & $\begin{array}{r}11 \\
6\end{array}$ & $\begin{array}{l}-.0 \cdot 12 \\
-0 \cdot 72\end{array}$ & $\begin{array}{l}>0.1 \\
>0.1\end{array}$ & $\begin{array}{l}-0 \cdot 32 \\
-0 \cdot 19\end{array}$ & $\begin{array}{l}>0 \cdot 1 \\
>0.1\end{array}$ \\
\hline
\end{tabular}

In all three groups the neonatal mortality. is insignificantly correlated with the overcrowding index. Infant mortality is significantly correlated with this index in the very large boroughs but not in the other two groups of smaller boroughs. No explanation suggests itself to account for this difference. The infant deaths were rather few in the third group of boroughs ( 27 and 37 in 1950-52 in the two smallest), but in the second group the smallest borough had 69 deaths. Paucity of deaths cannot be an explanation.

It is of some interest to see whether the relationship between the various indices of socio-economic status have changed during the period:

\begin{tabular}{l|c|c|c|c}
\hline \multicolumn{2}{|c|}{ Correlations } & $\begin{array}{c}1920-22 \\
r\end{array}$ & $\begin{array}{c}1930-32 \\
r\end{array}$ & $\begin{array}{c}1950-52 \\
r\end{array}$ \\
\hline $\begin{array}{c}\text { Percentage Occupied } \\
\text { Males in Social } \\
\text { Classes IV and } \\
\text { V and }\end{array}$ & $\begin{array}{c}\text { Persons per Room } \\
\text { more than two } \\
\text { to a Room } \cdots\end{array}$ & 0.744 & 0.739 & 0.757 \\
\hline $\begin{array}{c}\text { Percentage living more than two to a } \\
\text { Room and Persons per Room }\end{array}$ & 0.859 & 0.722 & 0.314 \\
\hline
\end{tabular}

* The City of London has been omitted from all the correlations in this paper since it has a very small and unusually constituted population. 
The large significant correlation between the proportion of occupied males in Social Classes IV and $\mathrm{V}$ and the number of persons per room has remained constant over the 30 years. The relationship between the proportion of occupied males in Social Classes IV and V and the percentage living more than two to a room had fallen below the level of significance in 1950-52 although a large significant correlation was found in the other two periods. The correlation between the two indices of density, which was very large in the two earlier triennia, fell significantly in 1950-52 but was itself still significant. The decline in the size of the correlation coefficients with the percentage living more than two to a room is directly attributable to conditions arising from the second world war. The destruction of so many houses led to an acute shortage and the opportunity was taken in the rebuilding programme to re-house Londoners outside the county boundaries. The result of this policy is that the population of London was one million less in 1951 than in 1931 (Table I), a decline of 23.9 per cent. at all ages, and of 30.9 per cent. at ages 0-15 years. The magnitude of the change is shown by the densities for the whole:

\begin{tabular}{|c|c|c|c|c|}
\hline Overcrowding Index & 1911 & 1921 & 1931 & 1951 \\
\hline $\begin{array}{l}\text { Percentage living more than Two } \\
\text { to a Room } \because \text { per Room } \\
\text { Average Persons per }\end{array}$ & $\begin{array}{c}17 \cdot 8 \\
1 \cdot 14\end{array}$ & $\begin{array}{c}16 \cdot 1 \\
1 \cdot 05\end{array}$ & $\begin{array}{c}13.1 \\
0.98\end{array}$ & $\begin{array}{l}2.5 \\
0.83\end{array}$ \\
\hline
\end{tabular}

\section{SUMMARY}

Between 1901 and 1931 the population of the County of London was approximately stationary. Between 1931 and 1951 it fell by over a million, and in seven of the 28 boroughs the population in 1951 was only about half that in 1931. The result of these changes was a great reduction in the proportion of persons living in overcrowded conditions. From 1901 to 1931 the proportion of the population living more than two persons to a room was between 1 in 6 and 1 in 8 ; by 1951 it had fallen to 1 in 40 .

From 1901 to 1931 about 3 per cent. of the population of London was foreign-born; in 1951 the figure was 5 per cent. for the County, and over 10 per cent. in four boroughs: Hampstead (16 per cent.), Kensington (12 per cent.), Paddington (10 per cent.), and St. Marylebone (12 per cent.).

The downward trend of the death rate during the 20 th century has been remarkably similar in the London boroughs, so that the boroughs with the highest and lowest rates in 1911-13 were in the same relative position in 1950-52. The fall, has, however, been larger in the boroughs where the rate previously was highest so that the actual and relative range of the death rates between London boroughs in 1950-52 was somewhat smaller than in 1911-13. The general death rate (standardized) is still significantly correlated with the indices of socioeconomic status (persons per room, and percentage in Social Classes IV and V).

The birth rate followed a trend similar to that of the death rate, and, generally, the relative level of the birth rate of a borough, high or low, has remained the same throughout the period. With the exception of the percentage of the population living more than two to a room, the correlations between the birth rate and the socio-economic indices have changed very little.

The very large fall in infant mortality in the London boroughs has been relatively greater in those boroughs where the initial level was highest. In 1911-13 and 1920-22, infant mortality was significantly correlated with the percentage of occupied males in Social Classes IV and V and with the two measures of overcrowding. In 1930-32 the correlations between infant mortality and overcrowding were reduced but still significant, while the percentage of occupied males in Social Classes IV and V was not significantly correlated with infant mortality. In 1950-52 the correlations between infant mortality and the three indices were not significant. The lack of correlation in 1950-52 was partly due to the increasing contribution made by neonatal mortality, and partly to the fact that the relationship is no longer demonstrable in the smaller boroughs although it still exists in the largest boroughs. If the neonatal component is excluded, the correlation of infant mortality for the first year of life is significant in 1950-52 for each of the three socio-economic indices. The successful efforts to reduce overcrowding have lessened the sensitivity of this index of socio-economic conditions. In 1911 the percentage of persons living more than two to a room ranged from 3.9 to 39.8 in the London boroughs, while in 1951 the range was only from $1 \cdot 3$ to $4 \cdot 6$; thus this index of overcrowding was no longer a measure of either the vital-statistical or socio-economic differences between the London boroughs in 1950-52.

\section{REFERENCES}

Heady, J. A., Daly, C., and Morris, J. N. (1955). Lancet, 1, 395. Heron, D. (1906). Drapers' Company Research Memoirs. 'Studies in National Deterioration. I. On the Relation of Fertility in Man to Social Status". Dulau, London.

Hersch, L. (1943). Med. et Hyg. (Gèneve), 0, 10.

McKinlay, P. L. (1928). Lancet, 2, 938.

Mitra, K. (1937). J. Hyg., 37, 108.

Stocks, P. (1928). Ann. Eugen. (Camb.), 3, 194. 